\title{
Investigation and design of the Plover Cove Water Scheme
}

\author{
by \\ S. E. H. Ford, M.C., M.A., M.I.C.E., M.I.W.E. \\ and \\ S. G. Elliott, S.M., B.A., B.A.I., M.I.C.E., M.I.W.E.
}

Sir Robert Wynne-Edwards, Past-President (Constructors, John Brown, Ltd), who opened the discussion, said his reason for speaking was that in 1965 he and the Secretary, accompanied by Dr Szeto, who was Chairman of the Joint Group in Hong Kong, had visited this great and imaginative project. He welcomed, therefore, the opportunity of congratulating the Authors and their firms and of thanking them for their great kindness on that extremely interesting visit, when it had been possible to see much of the work in hand.

102. The problem of providing enough water for the fast-growing and bustling colony of Hong Kong was a difficult one and every available source had to be tapped. The project which the Authors described was a notable one by any standards. The idea of storing water in what had previously been an area of the sea, the dam itself, which was designed to allow considerable settlements, the huge purpose-built dredger and placer for building the main dam, the auxiliary works, including the neoprene weir (which had been inflated to show how it worked), the $30 \mathrm{ft}$ diameter tunnel between the dams and Tai Po Tau, designed to carry water either way, the water treatment plant near Sha Tin, and the arrangements there to control the whole system when in operation, were splendid examples of what could be done by using the most modern engineering techniques.

103. Speaking for the Secretary as well as for himself, he said that their best wishes went to the Authors and their firms for the successful completion of the project, which would be a major achievement in the engineering world.

Mr N. A. F. Rowntree (Water Resources Board) said that barrages were a subject of discussion in Great Britain at that time and, since the responsibility for investigating the feasibility of two barrages had been placed on his Board, he was not only interested in the Paper but very pleased to see it presented at the Institution. The Plover Cove scheme had made it clear that works of this size could be carried out by British engineering firms, and the Water Resources Board had shown their confidence by asking British engineering consultants to look at the feasibility studies for which the Board were responsible.

105. Another important feature of the Paper from a public relations point of view was that it indicated the magnitude and complexity of the problems involved in carrying out this type of work. The rather light-hearted way in which requests for a barrage were sometimes made could be embarrassing, and he had been pleased to hear the procedure which had been adopted in Hong Kong. The foundations of the argument were the great need for water, the problem of providing storage for the adequate rainfall of the island, and the difficulty of finding a land location for this storage. To take advantage of the nature of the coastline and provide a barrage, had been a logical sequence of thought.

106. After a great deal of consideration it had been decided that if a barrage

* Proc. Instn civ. Engrs, 1965, 32 (Oct.) 255-293. 
were to be built in Great Britain at one of the sites considered for the purpose it would be primarily for reasons of water supply. It followed from this decision that the Water Resources Board should co-ordinate the feasibility studies for constructing barrages at Morecambe and Solway.

107. The terms of reference for these studies were quite complicated and involved everything from the initial stage of inspecting the site and making aerial surveys to the final decisions, including the consideration of ancillary uses to which the barrage could be put, the quantity and quality of water which could be made available, and the effects on the many interests which would be involved. Such studies were expected to take three years, and there was provision for breaking them off should a negative decision be reached at any stage. Such decisions were difficult to make.

108. At the same time as studies were being made of the feasibility from an engineering point of view, there would be parallel studies of what to do with the water which would become available. The Authors had made some reference to this. At Hong Kong there was the problem of distributing large quantities of water from a source at sea level, but if the Morecambe and Solway barrages were constructed the amount of water to be disposed of to make the schemes reasonably economic would require a distribution system over most of England north of the Mersey and Humber. At the same time it was necessary to look at both the conventional and unconventional sources in the area to consider whether these would provide better solutions than the barrage schemes.

109. He thought it might be of interest to mention the procedure in Great Britain on projects of a type similar to that at Hong Kong. It was interesting also to compare the scale of the operations. It was impossible not to be impressed by the scale of the Hong Kong project as indicated in the Paper; however, at Plover Cove the tidal range was about $8 \mathrm{ft}$; at Morecambe it would be over $20 \mathrm{ft}$, and for the Wash of the order of $27 \mathrm{ft}$. The length of the Plover Cove barrage was well over $6000 \mathrm{ft}$ (about $1 \mathrm{t}$ miles), whereas the length at Morecambe could be about 11 miles, and at the Wash about 16 miles. This gave some measure of the scale of the projects to be investigated in England.

110. There had been some comment about the amount of money which could be allocated for carrying out these preliminary investigations. It was of interest that sums varying from $£ 10000$ to $£ 35000$ or $£ 50000$ had been mentioned. The present proposed expenditure on the study of two of the barrages was about $£ 300000$ for each. From Appendix 2 it would be seen that the cost of the investigations at Hong Kong had amounted to about $£ 600000$. It would be interesting to know whether this figure related mainly to the barrages and the dams or whether other investigations had been included in the sum. If other investigations had played a substantial part it would be very helpful to those concerned in Great Britain to know how much had been allocated to the primary project.

111. Another item of interest regarding costs was that the cost of the dams was about $£ 17 \mathrm{~m}$. out of a total cost of about $£ 46 \mathrm{~m}$. The cost of the remainder of the scheme-pumping station, pipe-lines, tunnels for the distribution of the water, etc.was twice the cost of the original headworks, so that it was not just the cost of the barrage itself which was involved in making water available, but the cost of the large distribution system which had to be created for it.

Professor A. W. Bishop (Imperial College) said that the Authors had discussed in a very small space a very wide range of engineering problems, all of them of great interest, and it was perhaps difficult to focus on any one particular point. He wished, however, to comment briefly on certain features of the Plover Cove Dam and of the Lower Shing Mun Dam.

113. He wished first to make a few remarks on the use of drainage layers for accelerating the consolidation of fill placed in a nearly saturated condition. Drainage 
layers had been used for that purpose for the first time, so far as he knew, on the Usk Dam about 1951, on the advice of himself and Professor Skempton, to control the extremely high pore pressures which had arisen at the end of the first season's construction of that dam. The spacing used was about $40 \mathrm{ft}$ between centres. The layers had been put in as a remedial measure and had not been included in the original design, but no change in the external appearance of the dam had been involved. ${ }^{25}$

114. At a subsequent date, on the Selset Dam, built of less permeable clay under similar high rainfall conditions, drainage layers at about $15 \mathrm{ft}$ centres had been included from the outset in the initial design. Descriptions of the construction and performance of the embankment were given in papers by Kennard and Kennard, ${ }^{26}$ and Bishop and Vaughan. ${ }^{27}$ A study of the anisotropy of the fill with respect to flow of water during its consolidation had also been made in the first season's fill, using in addition vertical drains at $50 \mathrm{ft}$ centres and both horizontal and vertical lines of piezometers, as in the test mound described in the present Paper. At Selset there had been little evidence of anisotropy in wet-rolled fill. Perhaps the Authors would say whether or not their results showed that anisotropy resulted from segregation as a result of underwater dumping at Plover Cove; in other words, whether the horizontal and vertical permeabilities were very dissimilar.

115. Plover Cove represented the extreme end condition of wet-weather placement, the fill being placed completely under water, and no compaction equipment being used. Drainage layers were clearly a logical way of reducing the excess pore pressures at rates compatible with the rapid completion of the embankment. That extreme condition, however, might not be as bad as it sounded. At the Usk Dam the excess pore pressure had been nearly $100 \%$ of the weight of soil above, while in the case of the Lower Shing Mun Dam it was $65 \%$. Even if underwater placement gave $100 \%$ saturation the pore pressure could not exceed $100 \%$ of the weight of soil above. With underwater placement the void ratio was higher, and the permeability would therefore be higher, and in low clay fraction fills, such as decomposed granite, the rate of consolidation of the less compact underwater fill might actually greatly exceed that of a rolled fill of the same material. The rapid gain in stability of the underwater fill might therefore more than compensate for its high initial pore pressure. Perhaps the Authors would comment on this point and say whether or not, in comparison with the Lower Shing Mun Dam, the rate of consolidation for similar materials had proved to be more rapid with the underwater fill.

116. He would also like the Authors to say whether or not the values for rate of pore-pressure dissipation which had been assumed in the design on the basis of the test mound and laboratory tests were being confirmed by the large-scale operations carried out later.

117. With regard to the Lower Shing Mun Dam, the Authors were to be congratulated on arranging to build a well-instrumented dam on a site where a rapid draw-down of $150 \mathrm{ft}$ in 5 days was a practicable possibility. At the present time there was a shortage of satisfactory and reliable observations on the pore pressures set up on draw-down with which to confirm the design methods currently used, and a design might be unsafe or over-conservative simply through lack of detailed knowledge on this point. It was to be hoped that the Authors would take the opportunity of recording and publishing the pore pressure changes during a complete rapid draw-down.

118. Would the Authors say whether or not, in the design for rapid draw-down conditions, they had envisaged pore pressures as high as those indicated or implied by the results obtained by Paton and Semple ${ }^{28}$ for the Glen Shira embankment? In Professor Bishop's view, no new earth- or rockfill dam should receive its final certificate under the Reservoir Safety Act, or its local equivalent, until rapid drawdown had been carried out under design conditions.

119. He had one question about the inclined base to the core at Lower Shing 
Mun, shown in Fig. 16, on the lower left-hand side As the fill consolidated, would not the core tend to move upstream (to the left) and shear off the $8 \mathrm{ft}$ unreinforced top of the spear-head? Perhaps the Authors would comment on this and say whether they thought it would matter if the spear-head was sheared off.

120. Finally, as a yachtsman, he had been horrified by the danger referred to in $\$ 37$ of 'people in open boats suffocating in the dense midge clouds'.

Mr I. K. Nixon (Soil Mechanics, Ltd) said that the Authors had shown in their introductory film one method that was used for taking so-called undisturbed samples of soil with the standard 4 in. open-drive sampler. As the representative of the principal Contractor responsible for the execution of the investigation, he would like to describe another method which was available. He referred to the Swedish foil sampler, for taking long undisturbed samples of soft strata. So far as he knew, that method had never yet been used in this country, and when he had been arranging purchase of the equipment for his company, in 1960, there had been only about half-a-dozen sets outside Sweden. As a result of his experience with this equipment, he believed that it represented one of the most refined forms of undisturbed sampling for the purpose in question. It had been invented by the late W. Kjellman and T. Kallstenius for studying glacial lake clays in Sweden, with their numerous alternating laminations of soft clays and sand or silt.

122. Basically the equipment was a fixed piston type of sampler. In such equipment a piston closed the lower end of the sampling tube until such time as the level was reached where sampling was to commence. Thereafter it was held firmly fixed in position, with respect to ground level, in order to minimize subsequent compression or swelling of the sample along the tube. Wall friction inside the tube, however, caused drag on the sample and it had been shown by experiment that when the penetration exceeded 5 to 25 times the diameter, serious disturbance began to take place. The Swedish foil sampler was designed to overcome the problem of internal friction.

123. Fig. 21 illustrated the principle of the equipment, which was to encase the sample, as soon as possible after it had been cut, in a ring of steel strips or foils. These foils, which were attached to the piston, unwound from reels in the sampler head, and they remained in position thereafter, supporting the soil and taking its weight, as the sampler head and the tubes were driven downwards past the soil inside, in order to lengthen the sample.

124. The investigation at Plover Cove was the first occasion on which the equipment had been operated from floating craft. In order to fix the sampler piston they had used boring casing, braced to the craft and supported by two wooden pads on the sea bed. The standard Swedish head frame fitted on top of the casing, independent of the movement of the craft. Link rods connected the piston to the head frame. Fig. 22 illustrated the arrangement.

125. Sixteen reels of foils fitted into the magazine in the sampler head for encircling the $68 \mathrm{~mm}$ dia. sample. Each foil was about $\frac{1}{2}$ in. wide, and various thicknesses were available, depending upon the soil type and sample length required. The longest sample possible was $\mathbf{4 0}$ metres. A thin cutting shoe extended sufficiently far below the magazine to be outside the latter's zone of disturbance during driving.

126. The sampler head was lowered inside the boring casing on sampler tubes, each $2 \frac{1}{2}$ metres long, to the required sampling level. At this level the piston, to which the foils had been attached during the initial assembly, was unlocked. A special automatic clamp prevented it slipping downwards. Jacks on the craft were used to obtain a steady uniform penetration. A heavy solution of trichlorethylene oil was pumped down from the surface to the sampler head in order to lubricate the foils as they passed along the tube and to maintain pressure around the soil. A hydraulic ram in the head frame measured the piston load, as this needed to be carefully controlled during sampling in order to keep the correct tension in the foils. 


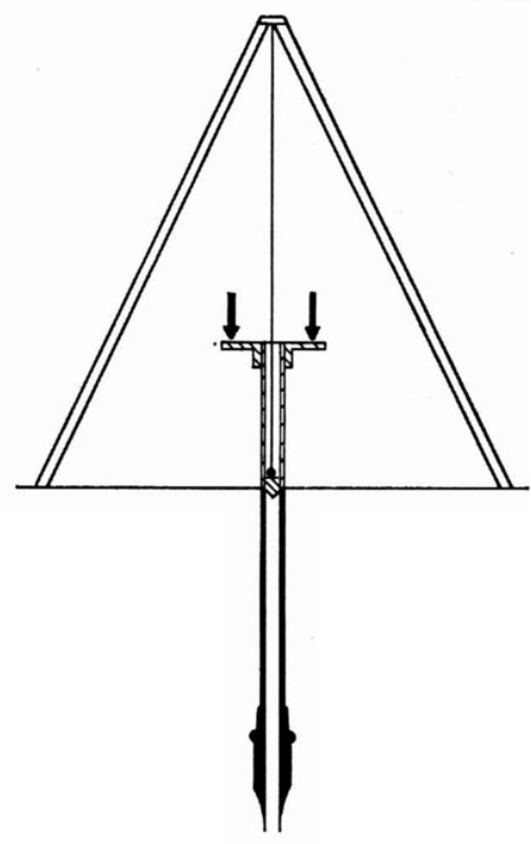

GENERAL LAYOUT

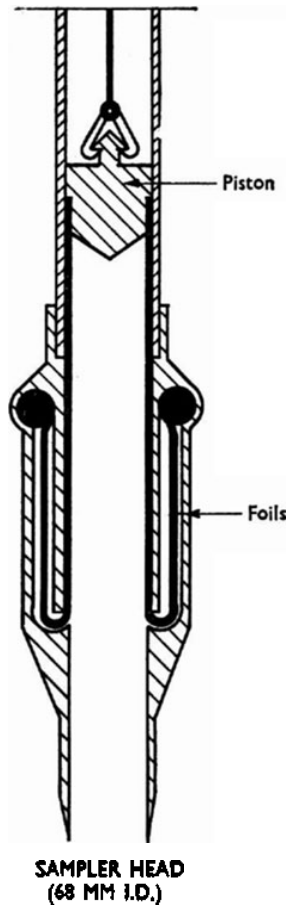

Fig. 21

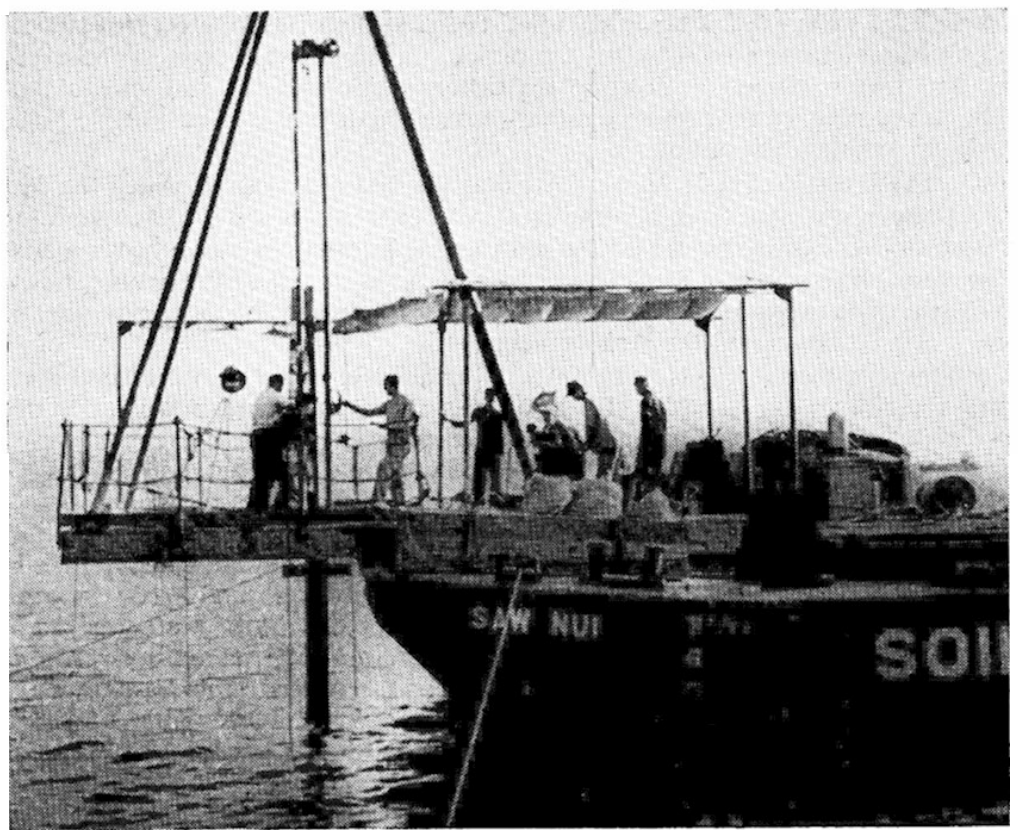

Downloaded by [] on [26/04/23]. Copyright (C) ICE Publishing, all rights reserved.

FIG. 22 


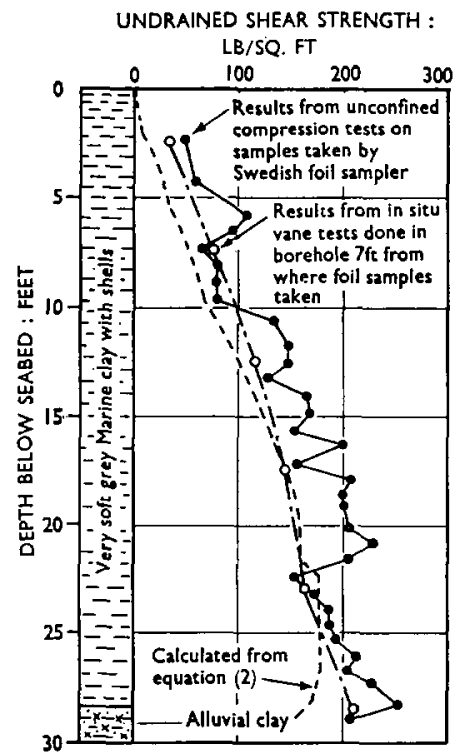

(a) PROFILE OF SHEAR STRENGTH
MOISTURE CONTENT : $\%$

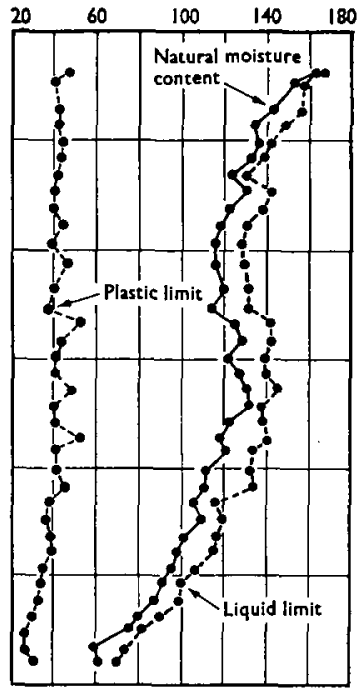

(b) PROFILE OF MOISTURE CONTENT AND LIMITS
DRY DENSITY : LB/CU. FT

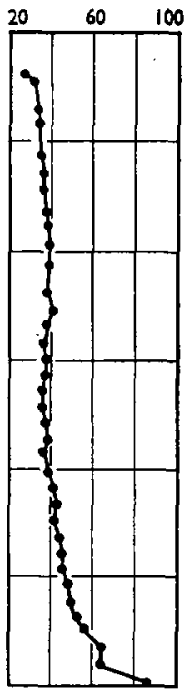

(c) PROFILE OF DENSITY

FIG. 23

127. The subdivision of the sample during withdrawal was accomplished by means of split couplings, which allowed the tube sections to be disconnected without unscrewing. After removing the couplings, the foils were cut as shown in Fig. 6, and then doubled back to support the soil in the remaining tubes awaiting the withdrawal. A split cap was inserted to support the soil in the upper tube as it was removed.

128. Perhaps the most interesting result of this type of sampling was the shear strength results obtained from unconfined compression tests on specimens cut from the marine clay in Plover Cove. Fig. 23 showed a typical case where they were in close agreement, and sometimes even higher, than vane strengths obtained some $7 \mathrm{ft}$ away from the foil sample (reproduced from a paper by J. K. Holt ${ }^{29}$ ).

129. In one case when the sample was split longitudinally, the imprint of a plant was revealed, complete with its roots and flower head, just as it had been engulfed in the steadily rising mud deposited around it. There was no sign whatever of any shear or deformation. That, he suggested, was very interesting evidence of the reliability of this technique.

The Chairman (Mr F. H. Allen) observed that the Paper formed a very good illustration of one of the problems which faced the Institution. It dealt with a scheme costing $£ 46 \mathrm{~m}$. and of enormous complexity, with barrages, drop-shafts, tunnels, weirs, pumping stations, water-treatment plant, problems in hydraulics and soil mechanics, etc, but it had been necessary to confine the Authors to little more than 5000 words. The Authors had therefore had to describe some of the many original features of the scheme very briefly indeed.

131. To illustrate what he had in mind, he referred to one aspect of the work with which he had himself been concerned. The drop-shaft referred to in $\$ \S 83$ and 84 
presented a very interesting hydraulics problem, and the Board of the Hydraulics Division had considered whether it alone might form the subject for a complete Paper. There were several other items in the present Paper which might usefully be amplified in this way. While congratulating the Authors, therefore, sympathy must also be expressed with them for having to operate under cramped conditions.

132. The Paper was also interesting in that it illustrated the extraordinary things that engineers were asked to do. Hong Kong was a tiny corner of rock at the edge of the largest continental land mass in the world, into which, for purely political reasons, a tremendous number of people had been pouring for years. For political reasons too, it was desirable that this small corner of rock should be self-sufficient in water, and so the Engineers were asked to supply 4 million people with water from an area of about 400 sq. miles.

133. In Appendix 2 the Authors had set out very clearly and interestingly the actual costs of the scheme, but had said almost nothing about its economic background. It would represent a capital investment of about $£ 46 \mathrm{~m}$., and in addition would involve fairly large costs for operation, maintenance, and so on. How was this to be paid for? What would the water rate be? How much would users pay per thousand gallons of water? This was particularly important in an area where probably three-quarters of the population could not afford to pay anything at all for water. It would be interesting to hear something about the economic and political background to the scheme.

134. He wished to refer to one of the models with which he had had a little to do some time previously, namely the general tidal model. This was fairly straightforward, as models went, but had had to be built in order to obtain certain information. It consisted of a shallow concrete tank, with an automatic tide-generating machine at one end to raise and lower the level of the water. As the tidal prism of the model filled and emptied, the water had to flow through the gap in the partially constructed dam, the width and invert level of which varied in different tests. Current velocities across the gap and vertical velocity profiles were then measured. No tests had been carried out in this model to examine the erodability of different materials. This had been dealt with in quite separate flume tests.

135. While he believed the model had been necessary at the time the tests were called for, did the Authors think that this relatively simple job could now be done better by a computer, or was there a prospect of being able to do such a job more cheaply and quickly by a computer in the fairly near future?

Mr I. P. Haigh (Research Engineer, Sir Alexander Gibb \& Partners) agreed with what the Chairman had said about the remarkable range of points of interest in the Paper and expressed the hope that at a later stage in the construction of this most important scheme a second Paper would be presented.

137. The question of storm surges was of considerable personal interest to him. In $\S 21$ the Authors wrote that the maximum height of a storm surge actually proved in Tolo Harbour had been $14 \mathrm{ft}$. In the next paragraph they referred to a Paper by J. J. Robson ${ }^{6}$ and specifically to an empirical relationship for estimating the heights of surges caused by typhoons.

138. This expressed the height of a surge as the product of the fall in atmospheric pressure at the eye of a typhoon and of a factor which was supposed to be constant for a particular maritime site. The barometric factor was, of course, a measure of the intensity of the original disturbance caused by the storm off shore, and the second factor, $k$, might be held to take account of the influences of shore lines on the magnification in amplitude as the disturbance moved inshore and entered bays and estuaries. The determination of $k$, which doubtless could vary considerably over short distances along a coastline, was, of course, the main difficulty in forecasting the height of a surge, and Robson had made no attempt to generalize on it. 
139. It was perhaps valid, however, to regard storm surges as being to some extent similar to ordinary tides. Both comprised initial disturbances in sea level and both caused long-period wave oscillations of greater amplitude to occur on coastlines of favourable shape. There were reasonable grounds, therefore, for trying to find a relationship between values of $k$ and tidal ranges at particular points.

140. Records of the storm surge that occurred on the German coastline in February 1962 provided a particularly well documented case of a single storm, measured at a number of autographic tide gauges ${ }^{30}$. He did not propose to mention in his contribution to the discussion a correlation between $k$ values for that German storm and actual tide ranges at the gauging stations. Instead, he would prefer first to find reasons why two of the tide records resolutely refused to fit the excellent pattern set by the others. Even at this stage, however, it seemed to be fairly certain that the heights of storm surges were closely proportional to ordinary tide ranges.

141. In Plover Cove the range of tides (H.H.W. to L.L.W.) was given in Fig. 13 as $8.0 \mathrm{ft}$. At Hong Kong itself the range was $4.9 \mathrm{ft}$, and he would suggest that the heights of surges at Plover Cove were therefore about $60 \%$ greater than at Hong Kong. On the only occasion that records, reported by Robson, had been taken at the two points together, the ratio had actually been 2.0 and not 1.6 ; however, this was much closer agreement than that provided by the investigations of I. E. M. Watts, also reported by Robson, to the effect that the highest surge recorded at Hong Kong was $6 \frac{1}{2} \mathrm{ft}$ and that surges of $13 \frac{1}{2}$ to $25 \mathrm{ft}$ had been measured at Tolo. The latter seemed to be much too high.

142. Tolo Harbour appeared to be of considerable tidal interest, for the range of $8.0 \mathrm{ft}$ at Plover Cove might be contrasted with a range of only $4.5 \mathrm{ft}$ in the nearby Tide Cove. The second figure had been obtained from the Admiralty Tide Tables. Had the Authors considered what effects the construction of the Plover Cove Dam would have on tide ranges in the harbour as a whole, and possibly on the heights of storm surges?

143. Another point of interest about the German storm of 1962-which, incidentally, was not to be dismissed as of no consequence in comparison with a typhoon, since the barometer had fallen to below 960 millibars-was the duration of the surge. At Cuxhaven the rise above mean sea level, roughly sinusoidal in form, had lasted for over 30 hours. It was sometimes held that storm surges could not coincide with high water, but evidently that had not been the German experience and it seemed to him that the duration of surges demanded much more careful consideration.

144. Salt-water infiltration was at the present time a subject of much topical interest in several parts of the world, and the Plover Cove Dam was noteworthy in that for a considerable part of the year the level of the water in the reservoir would be drawn down well below mean sea level. It would be interesting to learn what steps were being taken to prevent the entry of salt water, particularly as it appeared that the dam was to be founded on a considerable thickness of alluvial deposits, in part of sand and gravel. As it was sometimes overlooked, it might be worth while to repeat that the Ghyben-Herzberg interface depended for its stability not upon a hydrostatic balance but upon hydrodynamic considerations, and that it was important to recognize the need for ground-water to be kept in controlled motion if salt-water ingress was to be prevented. Were provisions to be made in the design of the dam to control these movements, possibly by installing pumps to act as hydraulic sinks?

145. He wished to make it clear that he was excluding arch dams, but for some years now an impression had been forming in his mind that both mass concrete and soils, considered as the major alternatives in the construction of gravity dams and earthfill dams respectively, were far from ideal materials and that improved construction techniques might shortly be possible. In concrete gravity dams a tremendous effort was made in preparing vast quantities of aggregate, mixing them with the minimum quantity of cement, and placing the concrete so produced in situ in the 
hope that shrinkage cracks and joints would not cause serious leakage problems. The class of concrete was of indifferent quality when judged by modern structural standards and possessed no merit other than its own weight. Earthfill dams used even greater quantities of materials which were less costly and more readily processed, but which must first be so placed that they would stand up by themselves and then be able to support the active pressure of the water in the reservoir and resist its insidious effects beneath the dam.

146. It seemed to him that the stage had now been reached at which it was desirable to review the construction of gravity dams, including earthfill, in the light of materials of higher tensile strength, of concrete of much better quality, of vastly improved handling plant, and of the time that it took to build a major dam. Looking back to the war-time method of building small-scale blast walls of hollow concrete blocks, used instead of sandbags, there seemed to be scope for building dams of similar construction, but using much larger open-ended precast concrete cells, posttensioned if that was desired, filled with earth and jointed vertically to render the dam impermeable, either with grout or with bitumen. This form of construction had been used in recent years for grain silos, and the earth-filled cellular cofferdam used as a dolphin in maritime works was in some respects similar. The converse of this idea, namely the use of lean concrete blocks with vertical joints of gravel, had been developed by Dr Marcello about twelve years previously for the construction of the Platani Dam in Sicily.

147. The potential advantages of that proposal lay in the more efficient use of materials and in the considerable saving in construction time. Further, the important uplift pressures below a conventional dam would have very little influence, because it would be easy to provide drainage.

148. For the Plover Cove Dam, consolidation settlements of about $6 \mathrm{ft}$ had had to be taken into account, and there was also the question of forming a closure in a fast tidal stream. In this connexion it was well to remember that Dutch engineers were having second thoughts about closing dykes with the aid of caissons, and he would like to ask the Authors whether they had considered the use of caissons in the dam at Plover Cove.

Mr A. Penman (Building Research Station) supported what the Chairman had said about the need for further papers dealing with the most valuable work that the Authors had described. He found the dam at Plover Cove of particular interest because of the fascinating concept of building it under water; it was, as a previous speaker had said, the extreme case of wet weather construction. It would be very valuable for the Institution to have a paper describing in detail the construction of the dam, and in particular giving details of the pore pressure and settlement measurements during the draw-down conditions which must exist when the reservoir was first emptied to put in the fresh water.

150. He was delighted to learn that the B.R.S. equipment for measuring settlement and pore pressures had worked successfully. In the early stages of the discussion of this work they had been very concerned lest the complex system of tubes and conditions for balancing air pressure, etc. might not work. They were very glad to hear that it was behaving well.

Mr M. J. Kenn (Senior Lecturer in Civil Engineering, Imperial College, London) supported the Chairman's expressed views concerning the need for further papers on some of the more detailed aspects of the Plover Cove Scheme. Two most interesting air-entraining hydraulic structures had been described in this Paper, namely the vortex-drop shaft and the air-controlled siphon spillways. These structures were mentioned briefiy in $\$ \S 83,84$ and 85 of the Paper but each deserved closer attention.

152. The use of air-controlled siphon spillways in the present scheme was to be 
commended. Such siphon spillways had been used widely abroad (e.g. in Europe and in North America) and the particular advantages of these spillways had been well established. However, until comparatively recently there appeared to have been in the United Kingdom a surprising reluctance to use air-controlled siphon spillways, perhaps in part because the associated design methods still were inexact.

153. This inexactness of design methods for air-entraining hydraulic structures applied also to the vortex-drop shaft of the scheme under discussion and was emphasized in the final sentence of $\S 84:$ " [model] tests were performed at [scales] $1: 10$ and $1: 20$ to show up the scale effects of air behaviour'. Disagreements between the patterns of flow for simple Froude models of air-entraining hydraulic systems and their full-sized equivalents were well documented and had been commented on. ${ }^{31.32}$ However, $\mathrm{Mr}$ Kenn believed that very few, if any, air-entraining hydraulic models had ever been correctly tested in appropriately simulated environments and especially in 'atmospheres' of appropriately reduced pressures. Perhaps the various 'highaltitude' test chambers of the aircraft industry could be used for testing such airentraining hydraulic models in their correct environments!

The Chairman (Mr F. H. Allen) mentioned that although the Consultants had had vortex-drop shaft models built to scales of $1: 10$ and 1:20, the Hydraulic Research Station had also built another model to a scale of $1: 30$ because of the special need to determine scale-effects.

Mr H. Grace (Messrs Scott \& Wilson, Kirkpatrick \& Partners) dealt with the shear strength of the foundation materials at Plover Cove and remarked that what he had to say might amplify the comments of $\mathrm{Mr}$ Nixon and illustrate their importance. From Fig. 9 of the Paper it would be seen that there was remarkable agreement between the shear strength obtained by the unconfined compression test and that obtained by the in situ penetration vane test. That to him was surprising, because in many cases it was not so. Some ten years before he had been in charge of an investigation in Kowloon Bay for the new Hong Kong airport, which had had to be built on reclaimed land surrounded by rock mounds. The shear strength of the foundation was of considerable importance, and the conditions in Kowloon Bay were in many respects very similar to those in Plover Cove.

156. When they had carried out their investigation they had found that the shear strengths obtained by the in situ vane test were apparently double the strengths obtained by the unconfined compression test, and that had presented them with considerable difficulty. If they had designed their retaining wall on the results of the unconfined compression test it might have involved the Hong Kong Government in a further $£ 800000$ when compared with a design on the basis of the in situ vane test, so that it had not been an academic problem but one to be taken very seriously.

157. They had eventually solved it to their satisfaction by examining an existing sea wall, putting down a series of holes on a line at right-angles to that sea wall and analysing the stability. They had then found that the unconfined compression test was giving values which were very much too low, resulting in a factor of safety of 0.75 ; and, as the wall was still there and looking very safe, they concluded that that must be wrong. The in situ vane test gave a value of $1 \cdot 35$, which seemed about right. By the use of the foil sampler the Authors seemed to have been able to overcome this difficulty, and if they had done so it would be a great advance. He would be grateful if they would give some further information about the foil sampler and also say whether it had been successful in sampling the strata below the mud at the bottom of Plover Cove.

158. He asked the Authors also to give further information about the spray method for temporary support of the tunnel and to say something about the cost. 
The following contributions were received in writing:

Mr J. F. Cooke (Senior Experimental Officer, Ministry of Technology, Hydraulics Research Station) wrote that tests on closure of the main dam at Plover Cove were referred to in $\S 53$ of the Paper. These tests were made on a tidal model having a scale of 1:180 horizontally and 1:60 vertically. The cross-section of the dam, however, was modelled to a scale of 1:60 both horizontally and vertically. In addition to the tests with a closure gap $3000 \mathrm{ft}$ wide, tests were also made with a closure gap $750 \mathrm{ft}$ wide, but the former tests covered a wider range of conditions and included two types of spring tide and a neap tide.

160. The tides at Plover Cove were complex in character. At times there was a diurnal inequality which caused large differences between the morning and evening tides, and there were also superimposed oscillations which affected the flood in particular and caused it to rise in two distinct parts. Some of these features could be seen in the inset to Fig. 14. On this account unusual difficulties arose in attempting to evaluate flows in the closure gap by calculation.

161. Velocities were observed on the model in the centre of the closure gap throughout the tidal cycle. Table 2 showed the maximum velocities in the ebb and flood directions. The various stages of closure were defined by the level to which the crest of the rock mound had been raised. In some instances velocities were at or near to their maximum for only short periods of time, but this was not always the case.

162. It would be seen from the Table that with the closure gap $750 \mathrm{ft}$ wide the greatest maximum velocities were $9.7 \mathrm{ft} / \mathrm{s}$ in the ebb direction and $9.5 \mathrm{ft} / \mathrm{s}$ in the flood direction, using a spring tide with large diurnal inequality (such as that in January and July of any year). With the $3000 \mathrm{ft}$ wide closure gap, using the same type of spring tide, the greatest maximum velocities amounted to only $6.4 \mathrm{ft} / \mathrm{s}$ in each direction. The greatest maximum velocities were therefore considerably less with the wider gap and moreover they occurred at higher crest levels. It would be noticed that the differences in the maximum velocities with the two widths of gap were particularly marked at the lower crest levels.

163. Using a spring tide with small diurnal inequality (such as that in April and October of any year), and again with the $3000 \mathrm{ft}$ wide closure gap, the greatest maximum velocities were $6.6 \mathrm{ft} / \mathrm{s}$ and $7.2 \mathrm{ft} / \mathrm{s}$ in the ebb and flood directions respectively, i.e. a little faster than those with the previous type of spring tide. This result appeared surprising at first because the overall range of tidal water levels was smaller, being only $6.4 \mathrm{ft}$ as against $7.8 \mathrm{ft}$. However the rates at which water levels rose or fell were related to the durations of the various parts of the tidal cycle as well as to the range of water levels.

164. With a neap tide (such as that in April and October of any year) the greatest maximum velocity in the ebb direction was $5.3 \mathrm{ft} / \mathrm{s}$, while in the flood direction it was a little less. As could be seen from columns (4) to (7) of Table 2, the crest of the rubble mound could be raised to a level of nearly $+1 \mathrm{ft} P$.D., even at spring tides, without this maximum velocity being exceeded. It followed, therefore, that if the final stages of closure, above a crest level of about $+1 \mathrm{ft} \mathrm{P.D.,} \mathrm{were} \mathrm{undertaken} \mathrm{at}$ neap tides, the maximum velocity in the closure gap could be limited to $5 \cdot 3 \mathrm{ft} / \mathrm{s}$.

165. Supplementary tests were made to simulate uneven deposition of rock when building up the crest of the rock mound. For this purpose a central portion of the rock mound, amounting to $500 \mathrm{ft}$ of the total $3000 \mathrm{ft}$ width of the closure gap, was set at a level $3 \mathrm{ft}$ lower than the remainder. This arrangement was referred to as a 'composite crest'. Columns (10) and (11) of Table 2 gave the maximum velocities in the closure gap (using a spring tide with small diurnal inequality). Comparison with columns (6) and (7) would show that considerable increases in the maximum velocities occurred with the lower section of the composite crest at levels above $-1 \mathrm{ft}$ P.D.

166. A study was also made on the model of the flow on the seaward side of the 


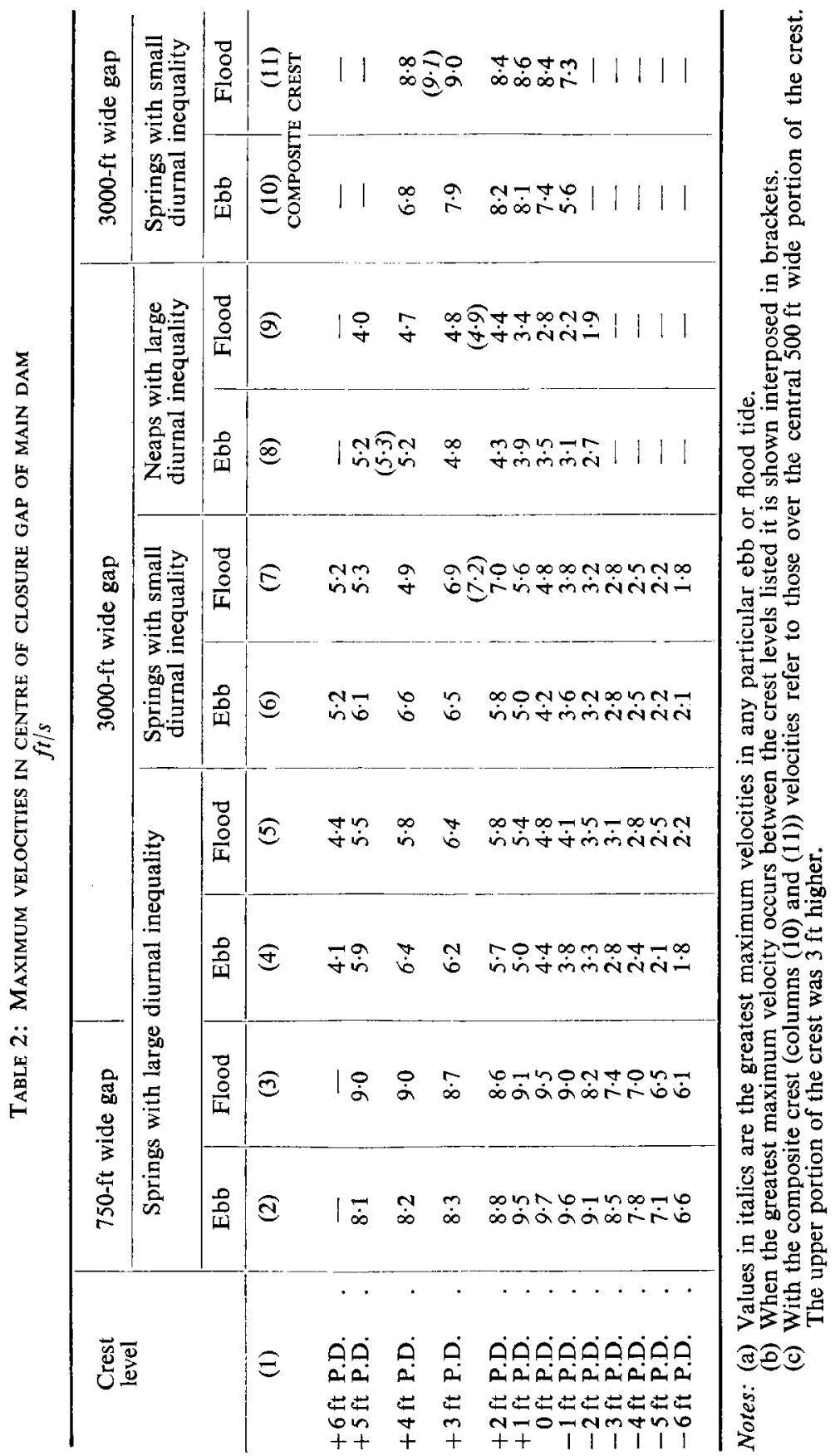

Downloaded b ${ }^{2}[]$ on [26/04/23]. Copyright (C) ICE Publishing, all rights reserved. 
dam during the ebb, and on the cove side of the dam during the flood, i.e. downstream of the dam in each case. Maximum velocities downstream of the dam, near the bed of the cove, were very much faster with the composite crest than when the crest was at an even level, being more than twice as fast in certain instances. Moreover areas affected by diving flow, when the main strength of the stream from the closure gap dived below the surface, were much more extensive. The general conclusions were that if the crest were raised evenly scour on the bed of the cove would be unlikely to occur, even at spring tides, but with uneven deposition of rock in the closure gap, as typified by the composite crest, the incidence of scour could not be precluded during the critical stages of closure.

Brigadier C. C. Parkman (Partner, Messrs Ward, Ashcroft and Parkman) wrote that he was particularly interested in the closure studies mentioned in the Paper. The tidal range given was $8 \mathrm{ft}$ and the maximum current, even at extreme tides during closure, was given as less than $9 \mathrm{ft} / \mathrm{s}$. This agreed closely with similar studies which the University of Liverpool had carried out for him in connexion with the Tidal Barrage at Milford Haven.

168. From a velocity bulb diagram, based on these studies, the maximum closure velocity, when tipping evenly over the width, was approximately $16 \mathrm{ft} / \mathrm{s}$ for a $26 \mathrm{ft}$ tide. The velocity bulb diagram indicated various closure velocities, at different states of the tide, at different embankment heights, and also for end tipping at various stages of construction.

169: He considered that the loss of $50 \mathrm{in}$./year of water from evaporation was high and wondered if the Authors, in the light of a further 12 months' experience, had been able to devise any method to reduce this.

170. With regard to the permeability, he asked what would be the maximum draw-down envisaged in the reservoir. He appreciated that the direction of flow through the embankment was generally from the fresh-water side towards the sea, but was interested in this extreme condition.

171. He would like to ask the Authors if, in fact, the results from the test mound had proved its worth. How much had it cost, and how were the piezometer/settlement cells placed?

172. Finally, having regard to the plan indicating the area where the materials were to be obtained (Fig. 2), he enquired of the Authors how much of the embankment could be placed by barge and how much in the dry? Perhaps they could give an indication of the relative costs of these two forms of construction.

The Authors in reply thanked all contributors to the discussion and, in particular, Sir Robert Wynne-Edwards for his kind remarks and good wishes for the successful completion of the project.

174. In reply to the Chairman and other contributors who had pressed for further papers, the Authors regretted that these were unlikely to be submitted to the Institution which had difficulties in fitting in all papers received. In the present Paper, it had been impossible to outline the more absorbing aspects of the scheme in fewer than 8000 words. Papers on the soils aspects and, in conjunction with the Contractors, on the construction of the Plover Cove dams and tunnels might be offered to other bodies.

175. Mr Rowntree had drawn interesting comparisons between barrage schemes in Britain and Hong Kong and had raised the question of costs of investigations. The Authors felt that most schemes were physically possible nowadays but a major problem lay in enough money and time being available for the considerable investigations needed to establish economic feasibility. Compromise was inevitable but if the risk of actual construction costs differing widely from the estimates were to be small, the unknowns had to be reduced to reasonable proportions by adequate investigations. The investigation costs in Appendix 2 of the Paper comprised: 
Preliminary feasibility studies and reports . . . . . . . . $\$ 12000$

* Fuller investigations for barrages and reservoirs . . . . . . . . . $\$ 380000$

* Fuller investigations for Lower Shing Mun reservoir, tunnels, intakes, pumping stations, and treatment works . . . . . . . . $\$ 178000$ Model tests

(* including full report for design and construction).

176. Although this total was only $1.3 \%$ of the cost of the whole scheme, the figure for barrage investigations represented more than $2.6 \%$ of the cost of the barrages. Moreover, substantial further investigations had to be continued during design and, indeed, during construction.

177. The preliminary feasibility studies had been cheap. That the estimates derived from them had not been far from those in the full report was fortuitous. The full study had been needed, however, to formulate a worthwhile integrated scheme in detail and to give estimates and recommendations with some degree of confidence.

178. Professor Bishop had raised many important questions concerning the designs of the dams. Drainage layers at $20 \mathrm{ft}$ centres had been allowed for provisionally in the design of the decomposed granite shoulders for Lower Shing Mun Dam but all except the four layers shown on Fig. 16 were omitted when it was confirmed that construction pore pressures in the shoulders were negligible. The lower layers had to be placed before enough readings were available for reasonable confidence to be established in the actual drainage properties of the fill. The upper layers were retained to guard against significant pore pressures developing due to changes in the character or placement moisture content of the fill and/or to increased rates of raising the embankment.

179. The figure of $65 \%$ quoted in the Paper was a design value for excess porepressure in a central zone of the core. Maximum values from 13 piezometers in the core ranged from $0-100 \%$ with an average of $53 \%$. Pore-pressure dissipation was rapid and the average value was only $17 \%$ on completion of construction. The Authors confirmed that the pore-pressure changes during rapid draw-down of the reservoir would be recorded for publication in due course. In the design for rapid draw-down, pore pressures as high as were implied in the Glen Shira Embankment results were not envisaged nor, so far, had they been obtained. Comparisons, however, were not easily made between the two cases.

180. The Authors agreed with Professor Bishop's point about reservoir safety but would qualify his requirement so that the design condition of draw-down need not itself be tested but that draw-down must be rapid enough for the design condition to be reasonably extrapolated. The point, of course, was that the design conditions might allow a factor of safety and it could well be impractical or unwise to attempt an extreme test.

181. Professor Bishop had drawn attention to the inclined base to the core shown on Fig. 16. In fact the base had been excavated to be horizontal in accordance with the detail also shown on Fig. 16. Had this not been so, the Authors agreed that there would be slight differential settlement but doubted whether the core would have tended to move upstream and shear off the spearhead.

182. Turning now to the main dam at Plover Cove, simplification of design had been possible by omitting the sand piles and mounds and by combining the two lowest sand drains (see Fig. 13). These and other changes were shown on Fig. 24.

183. Pore pressures were dissipating much more rapidly than assumed in the design and had not been troublesome. Excess pressures with respect to sea level to date had reached maxima of $18 \mathrm{ft}$ in the foundation and $21 \mathrm{ft}(\bar{B}=0.9,85 \%$ dissipation within 1 month) in the 'core' of placed fill; however, these figures were exceptional. 


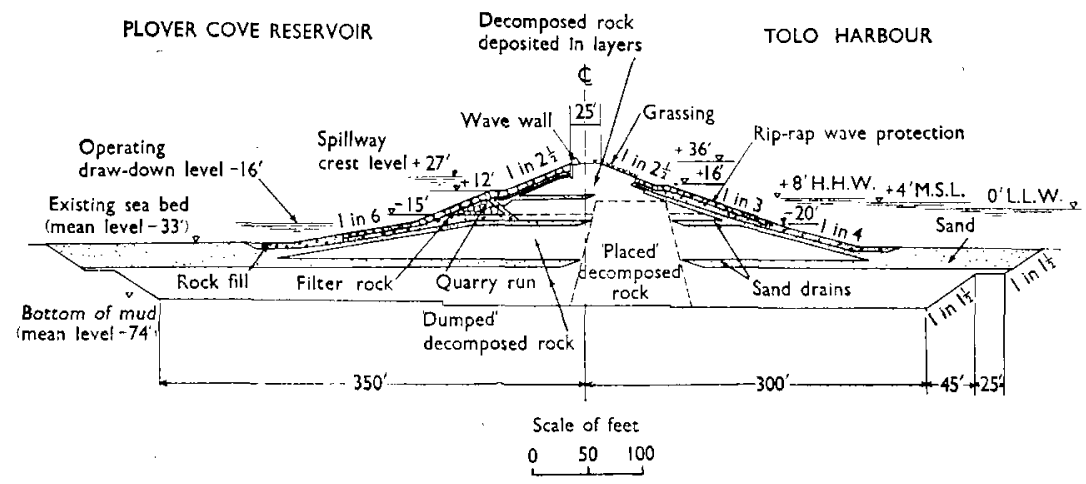

FIG. 24

184. Segregation of the fill material occurred during underwater dumping from bottom-discharge barges. Some segregation also occurred in the core material despite careful placement by clamshell. Thus the core was probably anisotropic to some degree but it was too early to give detailed figures. Field tests to date indicated an overall coefficient of permeability for the core in the range 0.5 to $2 \times 10^{-4} \mathrm{~cm} / \mathrm{s}$ with an average value of about $1 \times 10^{-4} \mathrm{~cm} / \mathrm{s}$.

185. The maximum settlements in the Plover Cove main dam, during the initial twelve-month period when the embankment was raised under water by about $45 \mathrm{ft}$, were about $1 \frac{1}{4} \mathrm{ft}$ in the foundation and $1 \mathrm{ft}$ in the embankment. At Lower Shing Mun, the maximum compression of the $200 \mathrm{ft}$ high embankment during construction (June 1963-December 1964) was about $4 \mathrm{ft}$; since completion, the dam had settled nearly $1 \mathrm{ft}$ at the centre of the crest. The Authors believed that there was no significant difference in the rate of consolidation of similar decomposed rock filling in the Plover Cove and Lower Shing Mun Dams.

186. The Authors considered that Mr Nixon's remarks about the Swedish foil sampler formed a useful supplement to the Paper, and thought that the sampler was the most refined practical tool for undisturbed sampling of soft strata.

187. In reply to the Chairman's enquiries about finance, water schemes in Hong Kong had been largely financed from revenue. The price of water for domestic purposes had been raised recently from $1 s 3 d$ to $2 s 6 d / 1000$ gal, the latter being the economic figure allowing some margin for financing future schemes. Water supplied to shipping and for building purposes was sold at $6 s 3 d / 1000$ gal. The cost of water, as opposed to the price, varied from well under $1 s$ for older, gravity schemes already amortized, to about $2 s / 1000 \mathrm{gal}$ for recent schemes. Costs of water for some future schemes were expected to be of the same order but, for others, they would rise to $2 s 6 d / 1000 \mathrm{gal}$, or more. Some water-not much-was provided free at public stand-pipes for those who could not afford to pay for it.

188. For the main dam closure studies, the Authors thought that crest velocities could have been ascertained by computer instead of the model test. In fact they had used a successive step method of calculation to establish the order of crest velocities to be expected for the likely range of closure gaps, before asking the Hydraulics Research Station to carry out the model tests. Theoretical studies by computer, however, could not have done the job of the model tests in demonstrating the patterns and effects of approach velocities, of pronounced downstream funnelling, of diving flow tending to erosion of the sea bed near the toe of the dam, or of uneven deposition of rock during closure. Mr Cooke's contribution referred usefully to some of these 
and other matters. In general, computers were no substitute for model tests in helping engineers to visualize a problem and, indeed, to see whether further problems could arise unexpectedly.

189. In reply to $\mathrm{Mr}$ Haigh, the maximum tidal ranges of Hong Kong Harbour, Plover Cove and Tide Cove were all much the same, at about $8 \mathrm{ft}$, with mean tidal ranges between 4.4 and $4.9 \mathrm{ft}$, which $\mathrm{Mr}$ Haigh had found in the tide tables. The coastal inlets around the Colony all experienced larger surges than those experienced in Hong Kong Harbour. The maximum surge of $14 \mathrm{ft}$ quoted in the Paper for Tolo Harbour in the 1937 typhoon was a substantiated figure and the comparable figure for Hong Kong Harbour was $7 \mathrm{ft}$. In 1964 good records of surges had been obtained, giving a factor of 2.0 between Tolo and Hong Kong Harbours. Thus typhoon experience in Hong Kong showed no correlation between surge and tidal range, nor did that theory seem to fit the records of American typhoons on the Atlantic coast and in the Gulf of Mexico. The Authors doubted whether the enclosure of Plover Cove would significantly affect tides or surges in Tolo Harbour. It was apparent that, in Tolo Harbour, the peaks of the larger surges lasted for quite short periods; for example, during typhoon 'Wanda' (September, 1962) the surge exceeded $6 \mathrm{ft}$ for less than three hours whereas the maximum surge was $10 \frac{1}{2} \mathrm{ft}$. However, they agreed that surge peaks coinciding with high water were indeed possible.

190. Although the level in Plover Cove Reservoir could be below mean sea level for years at a time, it was hoped to limit inward seepage to a low level by having an acceptable over-all coefficient of permeability for the dams, by relying upon the blanketing effect of the sea-bed mud (to limit flow through the foundations), by forming a cut-off of mud and decomposed rock through the beach deposits, and by grouting near the abutments and under the subsidiary dams. There was no present intention to install pumps to act as hydraulic sinks to control flow.

191. Amongst other methods, closure of the main dam with caissons had been considered, but this would have cost much more than closure with rock, which was plentiful near the site. The Dutch had imported rock about 100 miles from Belgium on their last major closure but still thought that it compared favourably with other closure methods.

192. Mr Haigh had made some stimulating general remarks about the design of dams other than arch dams. His dissatisfaction with ordinary mass concrete and soils as materials for dams was noted, but the facts were that earth dams were cheap and, on some sites, so were ordinary concrete gravity dams. Mass concrete in dams did have merits other than its own weight, e.g. it was usually durable, strong enough and quite homogeneous. With high-strength concrete, better handling facilities, cellular construction, prestressing and so on, it was possible to get out some good designs, but they might not be as cheap. Perhaps more people would try the experiment of putting such designs out to tender as alternatives.

193. The Authors confirmed to Mr Penman that the performances of equipment for measuring settlement and pore pressures were still satisfactory. They thought that the accuracy of each settlement reading would normally be within 1 in., which would be adequate.

194. Mr Kenn had rightly pointed out the virtual lack of air-entraining hydraulic models tested with correct simulation of environment. The Authors felt that testing under reduced pressures should be included in a full research programme on this subject, for which there was certainly much scope. Even with modelling of the vortex drop-shaft to no less than three scales in attempts to extrapolate the air effects (as Mr Allen had explained), the Authors had still been urged to try to have measurements taken on the prototype to enable reliable figures to be obtained.

195. Mr Grace had asked whether the Swedish foil sampler had been successful in the strata below the mud at the bottom of Plover Cove. This had been tried once but the outer casing of the sampler head had come off after $3 \frac{1}{2} \mathrm{ft}$ of penetration into 
the foundation strata. However, satisfactory cores of decomposed granite $22 \frac{1}{2} \mathrm{ft}$ long had been obtained in the test mound.

196. Sprayed concrete temporary support for tunnels was not cheap in direct cost but there were indirect savings in added safety, in time, and in the effective up-grading of the rock. Thus it was well worth inclusion at the design and tender stages as an alternative method of temporary and sometimes permanent support. Some excellent articles by Professor Rabcewicz ${ }^{33}$ provided detailed information about the method.

197. The Authors agreed with Brigadier Parkman that the evaporation loss of 50 in./year was considerable but they had not yet been able to devise a method of reducing it, molecular films so far being unsuited for reservoirs as large and exposed as Plover Cove.

198. The maximum draw-down envisaged in the reservoir would occur after pumping out the sea water, when the level would be at about $-30 \mathrm{ft}$ P.D. but for only a few months; during operation, the reservoir would be drawn down to $-16 \mathrm{ft}$ P.D.

199. The test mound had been essential and had cost about $£ 90000$. The combined piezometer/settlement cells were placed by a diver who then walked to the shore laying the leads.

200 . About $90 \%$ of the main embankment materials could be placed by marine and $10 \%$ by land plant. Placing in the dry cost on average $35 \%$ more than by barge.

\section{ADDENDUM}

The main investigation contractor was Soil Mechanics Ltd. Others were Yau Wing Company Ltd, Malayan Drillers (Hong Kong) Ltd and Oriental Boring Services Ltd.

\section{CORRIGENDUM}

The titles of the two lower graphs on the left-hand side of Fig. 12 in the Paper should be interchanged.

\section{REFERENCES}

25. Sheppard G. A. R. and Aylen L. B. The Usk scheme for the water supply of Swansea. Proc. Instn civ. Engrs, 1957, 7 (June) 246-274.

26. KenNard J. and KenNard M. F. Selset Reservoir: design and construction. Proc. Instn civ. Engrs, 1962, 21 (Feb.) 277-304.

27. Bishop A. W. and VAughan P. R. Selset Reservoir: design and performance of the embankment. Proc. Instn civ. Engrs, 1962, 21 (Feb.) 305-346.

28. Paton J. and Semple N. G. Investigation of the stability of an earth dam subject to rapid draw-down including details of pore pressures recorded during a controlled draw-down test. Proc. Conf. Pore Pressure and Suction in Soils. London, Butterworths, 1960, pp. 85-90.

29. Holt J. K. The soils of Hong Kong coastal waters. Proc. Symp. Hong Kong Soils, 1962, pp. 33-51.

30. Schulz H. Verlauf der Stormflut vom Februar 1962 im deutschen Küsten- und Tidegebiet der Nordsee. Die Küste, 1962, 10 (1) 5-16.

31. Stevens J. C. On the behaviour of siphons. Trans. Amer. Soc. civ. Engrs, 1934, 99, 986-1005.

32. ESCANDE L. Recherches sur l'écoulement de l'eau entre les piles de ponts. Génie civile, 1939, 115 (Aug. 5; Aug. 12; Sept. 23), 113-117; 138-140; 259-260.

33. RabCewicz L. v. The new Austrian tunnelling method. Water Power, 1964, 16 (Nov.; Dec.) 453-457; 511-515; 1965, 17 (Jan.) 19-24. 